\title{
PENGEDALIAN GULMA PADA TANAMAN KARET (hevea brasiliensis, Mull, Arg.) DI INSTALASI BENIH PERKEBUNAN KUALU UPT TPH BUN PROVINSI RIAU
}

\author{
Hendy Andrean ${ }^{1}$ \\ Jurusan Agroteknologi, Fakultas Pertanian, Universitas indragiri, Riau
}

Email: hendy.andrean1904@gmail.com

\begin{abstract}
Tanaman karet (Hevea brasiliensis Mull, Arg.) merupakan salah satu tanaman yang dibudidayakan di Indonesia dan memberikan andil yang cukup besar terhadap devisa negara diantara hasil perkebunan lainnya, dan menempati urutan ketiga setelah migas dan kayu (Setyamidjaja, 1993). Pengendalian gulma di kebun karet menghasilkan sangatlah penting untuk menekan jumlah pengeluaran dan meningkatkan hasil produksi. Pengendalian gulma harus mengikuti aturan yang dianjurkan. Kesalahan dalam pengendalian dapat mengurangi produksi lateks. Pengendalian dapat dilakukan dengan cara mekanis, kultur teknis, hayati, preventif, kimia dan pengendalian terpadu. Saat ini, pengendalian gulma secara kimiawi merupakan alternatif terbaik untuk skala perkebunan yang luas. Berdasarkan uraian di atas penulis menyusun usulan magang mengenai"Pengendalian Gulma Pada Tanaman Karet (Hevea brasiliensis) Di Instalasi Benih Perkebunan Kualu UPT TPH BUN Provinsi Riau ".
\end{abstract}

Kata Kunci: Pengendalian, Gulma, Karet, Instalasi, Kualu

\begin{abstract}
Abstrak
Rubber plants (Hevea brasiliensis Mull, Arg.) Are one of the plants cultivated in Indonesia and provide a significant share of the country's foreign exchange among other plantation products, and rank third after oil and gas and timber (Setyamidjaja, 1993). Weed control in mature rubber gardens is very important to reduce expenditure and increase production yields. Weed control should follow the recommended rules. Mistakes in control can reduce latex production. Control can be carried out by means of mechanical, technical culture, biological, preventive, chemical and integrated control. Currently, chemical weed control is the best alternative for large scale plantations. Based on the description above, the authors compile an apprenticeship proposal regarding "Weed Control in Rubber Plants (Hevea brasiliensis) in the Seed Installation of the Kualu Plantation UPT TPH BUN Riau Province".
\end{abstract}

Keywords: Control, Weeds, Rubber, Installation, Kualu

\section{PENDAHULUAN}

\subsection{Latar Belakang}

Tanaman karet (Hevea brasiliensis Mull, Arg.) merupakan salah satu tanaman yang dibudidayakan di Indonesia dan memberikan andil yang cukup besar terhadap devisa negara diantara hasil perkebunan lainnya, dan menempati urutan ketiga setelah migas dan kayu (Setyamidjaja, 1993). Selain dapat diambil lateksnya untuk bahan baku pembuatan aneka barang keperluan manusia, sebenarnya karet masih memiliki manfaat lain, yaitu dapat memberikan keuntungan bagi pemilik perkebunan dan memberikan 
hasil sampingan dari kayu atau batang pohon karet.

Produksi karet di Indonesia menempati posisi kedua terbesar dunia dengan luas areal seluas 3,45 juta hektar, hampir $85 \%$ adalah perkebunan rakyat yang melibatkan 2 juta kepala keluarga (Kemtan, 2012). Salah satu kendala peningkatan produksi karet di Indonesia adalah produktivitas yang masih rendah karena adanya organisme pengganggu tanaman, terutama gulma. Pengendalian gulma di perkebunan karet harus dilakukan karena dapat mengakibatkan persaingan dalam penyerapan unsur hara, air, cahaya, dan ruang tempat tumbuh. Gulma juga dapat menjadi tumbuhan inang dari hama dan penyakit tanaman.

Jenis-jenis gulma penting pada perkebunan karet diantaranya yaitu jenis gulma golongan rumput (Imperata cylindrica, Paspalum conjugatum, Ottochloa nodosa, dan Polygala paniculata; jenis daun lebar (Mikania cordata, M. micrantha, Melastoma malabatrichum, Clibadium surinamensis) dan jenis rumput teki (Cyperus kyllingia, C. rotundus dan Scleria sumatrensis) (Tjitrosoedirdjo, dkk, 1984). Tetapi informasi jenis gulma tersebut tidak didasarkan pada perbedaan umur tanaman karet. Selain itu dalam budidaya karet, pengendalian gulma menyerap biaya sebesar $50-70 \%$ dari seluruh biaya pemeliharaan selama tanaman belum menghasilkan (TBM) dan selanjutnya sebesar 20-30\% setelah tanaman menghasilkan (Mangoensoekardjo, 1983).

Pengendalian gulma di kebun karet menghasilkan sangatlah penting untuk menekan jumlah pengeluaran dan meningkatkan hasil produksi. Pengendalian gulma harus mengikuti aturan yang dianjurkan. Kesalahan dalam pengendalian dapat mengurangi produksi lateks. Pengendalian dapat dilakukan dengan cara mekanis, kultur teknis, hayati, preventif , kimia dan pengendalian terpadu. Saat ini, pengendalian gulma secara kimiawi merupakan alternatif terbaik untuk skala perkebunan yang luas. Berdasarkan uraian di atas penulis menyusun usulan magang mengenai"Pengendalian Gulma Pada Tanaman Karet (Hevea brasiliensis) Di Instalasi Benih Perkebunan Kualu UPT TPH BUN Provinsi Riau ".

\subsection{Tujuan penelitian} adalah :

Adapun tujuan dari penelitian ini

1. Meningkatkan kemampuan dan keterampilan mahasiswa dalam melaksanakan kegiatan akademik maupun secara praktek di lapangan..

2. Meningkatkan kemampuan mahasiswa dalam membandingkan penerapan teori yang di terima di akademik dengan praktek yang di lakukan di lapangan.

3. Mempelajari serta memperdalam pengetahuan dan meningkatkan keterampilan mahasiswa khususnya tentang pengendalian gulma pada tanaman karet.

\subsection{Manfaat penelitian} adalah :

Adapun manfaat dari magang ini

1. Terjalinnya kerjasama antara perguruan tingi dengan instansi atau perusahaan terkait.

2. Perusahaan memperoleh kesempatan berpartisipasi dalam pembangunan nasional melalui pengembangan sumber daya manusia.

\subsection{METODOLOGI}

\subsubsection{Tempat dan waktu}

Kegiatan penelitian m swa program studi Agroteknologi rakultas Pertanian Universitas Islam Indragiri Tembilahan akan di laksanakan selama 1 (satu) bulan yaitu di mulai pada tanggal 8 januari s/d 8 februari 2020

Lokasi magang bertempat di Instalasi Benih Perkebunan Kualu UPT TPH BUN Provinsi Riau.

\subsubsection{Metode Pelaksanaan}

Pada pelaksanaan kegiatan penelitian, mahasiswa di berikan kesempatan bekerja secara langsung di lapangan setara Karyawan Harian Lepas (KHL) dan mengikuti semua kegiatan yang ada di lapangan selama 4 minggu sesuai dengan Standar Operasional Prosedur (SOP).

Minggu pertama penulis di beri kesempatan untuk melakukan pengenalan terlebih dahulu dengan tanaman karet serta gulma yang ada dan pada hari berikutnya penulis di berikan kesempatan untuk memahami serta menguasai teknik pengendalian gulma secara kimia, hayati, serta manual dan cara pengaplikasiannya. 


\section{KEADAAN UMUM LOKASI INSTALASI}

\subsection{Letak Lokasi}

Instalasi Benih Perkebunan Kualu UPT

TPH BUN berada di Kabupaten Kampar Provinsi Riau tepatnya di bangkinang.

\subsection{Keadaan Tanaman}

Tanaman yang di budidayakan di Instalasi Benih Perkebunan Kualu UPT TPH BUN Kabupaten Kampar Provinsi Riau beranekaragam mulai dari tanaman musiman seperti sayur sayuran dan tanaman tahunan seperti kopi, kelapa, karet, kelapa sawit, jengkol dll.

\section{PELAKSANAAN KEGIATAN}

\section{PENELITIAN}

\subsection{Aspek Teknis}

Pada pelaksanaan kegiatan magang yang di laksanakan di Di Instalasi Benih Perkebunan Kualu UPT TPH BUN Provinsi Riau penulis di tempatkan sebagai Karyawan Harian Lepas (BHL) di lapangan. Kegiatan di mulai dengan apel pagi di lakukan pada pukul 07 : 30 dan di lanjutkan dengan melakukan aktifitas perkebunan sampai dengan selesai pukul 15: 00 WIB. Jenis pekerjaan yang penulis ikuti Sebagai KHL yaitu : Perbanyakan tanaman lada secara vegetatif, Pemupukan tanaman lada, pembibitan serta pemberian pestisida dan insektisida pada tanaman yang ada di Instalasi Benih Perkebunan Kualu UPT TPH BUN Provinsi Riau.

\section{TINJAUAN PUSTAKA}

\subsection{Klasifikasi Tanaman Karet}

Klasifikasi botani tanaman karet sebagai berikut:
Kingdom
Plantae
Subkingdom
Tracheobionta
Super Divisi
: Spermatophyta
Divisi
: Magnoliophyta
Kelas
: Magnoliopsida
Sub Kelas
: Rosidae
Ordo
Euphorbiales
Famili
Genus
: Hevea

Spesies: Hevea brasiliensis (Sumber Anwar, 2001)

\subsection{Tanaman Karet dan Morfologinya}

\subsubsection{Tanaman Karet}

Tanaman karet merupakan tanaman asli Brazil yang mempunyai nama latin Hevea brasiliensis. Tanaman karet adalah tanaman berumah satu (monoecus). Pada satu tangkai bunga yang berbentuk bunga majemuk terdapat bunga betina dan bunga jantan. Penyerbukannya dapat terjadi dengan penyerbukan sendiri dan penyerbukan silang. Penyerbukan silang terjadi dengan bantuan serangga seperti jenis-jenis Nitudulidae, Phloeridae, Curculionidae, dan jenis-jenis lalat.

Tanaman karet ( Hevea brasilliensis Muell Arg ) adalah tanaman getahgetahan. Dinamakan demikian karena golongan ini mempunyai jaringan tanaman yang banyak mengandung getah ( lateks ) dan getah tersebut mengalir keluar apabila jaringan tanaman terlukai (Santosa, 2007).

4.4.2. Morfologi tanaman karet sebagai berikut :

a. Akar

Tanaman karet termasuk ke dalam kelas Dycotyledonae. Oleh karena itu akar tanaman karet berupa akar tunggang dengan sistem perakaran padat atau kompak.

\section{b. Batang}

Batang umumnya bulat atau silindris yang tumbuh lurus dengan percabangan di bagian atas. Batang mengandung getah atau lateks. Karet yang dibudidayakan umumnya memiliki ketinggian antara $10-20 \mathrm{~m}$.

c. Daun

Daun karet berupa daun trifoliata dan berwarna hijau. Anak daun berbentuk elips dengan bagian ujung runcing. Tangkai daun panjang dengan serat daun yang tampak jelas dan kasar.

d. Bunga

Bunga karet merupakan bunga monoecious. Bunganya muncul dari ketiak daun (Axillary), individu bunga bertangkai pendek dengan bunga betina terletak di ujung. Proporsi bunga jantan lebih banyak di bandingkan bunga betina. e. Buah dan biji Buah umumnya memiliki tiga buah ruang bakal biji. Buah yang sudah masak akan pecah dengan sendirinya. Biji berwarna coklat kehitaman dengan pola bercak-bercak yang khas. Tanaman dewasa dapat menghasilkan sekitar 2.000 biji per tahun.

\subsection{Ekologi Tanaman Karet}

Daerah pertanaman karet yang ideal terletak antara 15o LU - 10 o LS. Sekalipun demikian, pada umumnya produksi maksimum lateks dapat tercapai apabila ditanam pada lokasi yang semakin mendekati garis khatulistiwa (5-6 o LU/LS).

\section{a. Iklim}

Sesuai dengan habitat aslinya di Amerika Selatan, terutama brasil yang beriklim tropis, maka karet cocok ditanam di daerah-daerah tropis lainnya. Tanaman karet, tanaman rendah tropis dan tumbuh yang tercepat di temukan pada letak ketinggian dari 200 m. Iklim merupakan 
faktor yang paling berpengaruh dari unsur iklim yang banyak diselidiki dan diketahui pengaruhnya adalah curah hujan dan suhu (temperatur). Kelompok iklim yang digunakan adalah atas dasar sistem klasifikasi tipe curah hujan dari schnidt dan ferguson :

Tipe A : Sangat cocok

Tipe B : cukup, sesuai

Tipe C : Kurang sesuai

Tipe D: tidak sesuai

\section{b. Curah Hujan}

Tanaman karet menghendaki daerah dengan curah hujan antara 1.500-4.000 $\mathrm{mm} /$ tahun dan merata sepanjang tahun dengan terbagi antara 100-150 per hari hujan dengan type iklim A-C dan daerahdaerah yang sering mengalami hujan pada pagi hari akan mempengaruhi produksi.

\section{c. Temperatur}

Suhu harian yang diinginkan tanaman karet rata-rata $250-300 \mathrm{C}$. apabila dalam jangka waktu panjang suhu harian rata-rata kurang dari 200 C, maka tanaman karet tidak cocok ditanam didaerah tersebut. Walaupun demikian, di daerah yang suhunya lebih tinggi, tanaman karet juga relative tidak sesuai.

\section{d. Intensitas Sinar Matahari}

Intensitas sinar matahari adalah hal yang sangat dibutuhkan tanaman karet dan sulit untuk ditawar. Bila terjadi penyimpangan terhadap faktor ini, maka mengakibatkan turunnya produktivitas. Di negara-negara tropis sinar matahari yang cukup melimpah merupakan syarat lain yang diinginkan tanaman karet. Dalam sehari tanaman karet membutuhkan sinar matahari dengan intensitas yang cukup, paling tidak selama 5-7 jam/hari

\section{PEMBAHASAN}

\subsection{Gulma pada Perkebunan Karet dan Pengendalianya}

Kemunculan gulma pada perkebunan apapun selalu dianggap sebagai penganggu yang merugikan dan perlu untuk dikendalikan. Tidak terkecuali pada perkebunan karet. Masalah gulma menjadi sangat penting karena gulma dapat menjadi kompetitor yang kuat bagi tanaman. Pengendalian gulma pada tanaman karet harus dilakukan ketika tanaman masih dalam fase pimbibitan, sampai dengan tanaman fase menghasilkan (TM)

\subsubsection{Gulma pada Perkebunan Karet}

Menurut Tim Penulis PS (2009), terdapat cukup banyak jenis gulma yang tumbuh pada perkebunan karet. Beberapa jenis gulma yang merugikan dan perlu untuk dikendalikan antara lain alang-alang (Imperata cylindrica), sembung rambat (Mikania micranta), krinyuhan (Chromolaena odorata), harendong (Melastoma malabathricum), pakis kawat (Glichenia linearis) dan ficus (Ficus sp.).

Sedangkan menurut Tjitrosoedirdjo, dkk. (1984) jenis-jenis gulma penting pada perkebunan karet di antaranya yaitu jenis gulma golongan rumput (Imperata cylindrica, Axonophus compressus, Panicum repens, Paspalum conjugatum, Ottochloa nodosa, dan Polygala paniculata), jenis daun lebar (Mikania cordata, M. micrantha, Melastoma malabatrichum, Ageratum conyzoides, Clibadium surinamensis, Dryopteris arida, dan Nephrolepsis hisserata), serta jenis teki (Cyperus kyllingia, C. rotundus, dan Scleria sumatrensis).

Dalam beberapa penelitian, Supriyadi (2001) mencatat jenis-jenis gulma yang terdapat pada perkebunan karet di Perkebunan Getas, Salatiga, Jawa Tengah adalah gulma dengan jenis daun lebar (famili Leguminoceae dan Borreria latifolia) serta gulma jenis rumputan (Panicum trichoides, Setaria berbata, dan Ottochloa nodosa). Sedangkan Mustikaningsih (2001) mencatat beberapa jenis gulma pada perkebunan karet di Cibungur - Sukabumi, diantaranya Boreria alata, Heydiotis corymbosa, Synedrella nodiflora, Digitaria ciliaris, Axonophus compressus, dan Cyperus kyllingia.

Gulma-gulma tersebut dikendalikan dengan cara mekanik, manual, bahkan kimiawi untuk menghindari persaingan antar gulma dan tanaman sehingga tidak terjadi kerugian dan kehilangan hasil akibat gulma yang tumbuh.

\subsubsection{Pengendalian Gulma pada Perkebunan Karet}

Kegiatan pemeliharan dalam

budidaya tanaman karet merupakan satu hal yang sangat penting untuk dilakukan karena akan menentukan keberhasilan budidaya itu. Keberhasilan pengendalian gulma merupakan salah satu faktor penentu tercapainya produksi yang tinggi. Tanpa adanya pegendalian terhadap gulma, maka akan muncul beberapa kerugian. Kerugian akibat adanya gulma antara lain menyebabkan pertumbuhan terganggu sehingga menyebabkan fase vegetatif lebih lama, terjadi penurunan kualitas dan hasil produksi (produksi lateks), kinerja yang ada di kebun (pemeliharaan) terganggu, mempersulit penyadapan, menjadi inang hama dan penyakit bagi tanaman, biaya 
pengendalian mahal, menekan pertumbuhan tanaman budidaya akibat alelokimia yang dihasilkan gulma (Barus, 2000; Triharso, 1994).

Gulma dapat dikendalikan melalui berbagai aturan dan karantina, secara biologi, secara fisik dengan merusak bagian tubuh gulma, melalui budidaya atau kultur teknis, secara mekanis dengan alat mekanis bermesin dan nonmesin, serta dengan cara kimiawi menggunakan herbisida. Pada fase TBM, pengendalian gulma dilakukan dengan menanam LCC (Legume Cover Crop) yang ditanam 1,5 - $2 \mathrm{~m}$ dari barisan tanam bersamaan dengan penanaman karet. Selain dengan menanam LCC, pengendalian juga dilakukan dengan melakukan pemeliharaan piringan ( $\mathrm{d}=1-1,5 \mathrm{~m}$ ) secara manual (pengoretan) dan juga kimiawi jika tanaman berumur >2tahun menggunakan herbisida (Tim Penulis PS, 2009). Menurut Tjitrosoedirdjo dkk. (1984) dan Setyamidjaja (1993), pengendalian TBM 1 - 5 dilakukan pada jalur (strip) tanaman karet dengan lebar 1 - 2 m ke kanan-kiri tanaman dengan frekuensi pengendalian sebanyak $2-4$ kali pada bulan Maret, Juni, September, dan Desember (Anwar, 2001).

Setelah tanaman karet memasuki fase TM, gulma akan dikendalikan dengan mengikuti anjuran. Pengendalian gulma pada jalur sadap dilakukan secara manual dan kimiawi. Pengendalian dengan cara manual/fisik tidak sering dilakukan pada budidaya tanaman karet, namun tetap dilakukan untuk mengendalikan gulma yang merambat di pohon. Pengendalian gulma secara manual/fisik yang seringkali dilakukan adalah membabat atau mengored (Tjitrosoedirjo dkk., 1984), sedangkan pengendalian secara kimiawi dapat menggunakan herbisida pasca tumbuh dengan merek dagang seperti Gramoxone $1,5 \mathrm{l}$ dalam 500 I air/ha, Ustinex $1 \mathrm{~kg}$ dalam 250 I air/ha, atau Round Up 1,5 I dalam 500 I air/ha (Tim Penulis PS, 2009). Pengendalian kimiawi pada tanaman menghasilkan dilakukan sebanyak 2 - 3 kali yaitu pada bulan Maret, Juni, dan September (Anwar, 2001).

Menurut Riadi dkk. (2011), herbisida merupakan suatu bahan atau senyawa kimia yang digunakan untuk menghambat pertumbuhan atau mematikan tumbuhan. Herbisida ini dapat mempengaruhi satu atau lebih proses dalam tumbuhan (seperti pada proses pembelahan sel, perkembangan jaringan, pembentukan klorofil, fotosintesis, respirasi, metabolisme nitrogen, aktivitas enzim, dsb.) yang sangat perlu dilakukan oleh tumbuhan untuk dapat mempertahankan kelangsungan hidupnya.

Herbisida bersifat racun terhadap gulma dan juga terhadap tanaman. Herbisida yang diaplikasikan dengan dosis tinggi akan mematikan seluruh bagian yang dan jenis tumbuhan. Pada dosis yang lebih rendah, herbisida akan membunuh tumbuhan tertentu dan tidak merusak tumbuhan yang lainnya. Kecepatan aksi herbisida dalam meracuni gulma bergantung pada kondisi eksternal; seperti kelembapan udara, suhu dan kadar air dalam tanah. Penggunaan herbisida pada perkebunan karet menjadi utama dikarenakan keefektifan dan keefisienannya. Dalam perkebunan karet terdapat beberapa jenis herbisida yang dapat digunakan untuk mengendalikan gulma pada tanaman karet adalah glifosat, parakuat (Anwar, 2009 \& Kementan 2011), diuron, oksifluorfen, dan metil metsulfuron (Kementan, 2011).

\section{KESIMPULAN DAN SARAN}

\subsection{Kesimpulan} bahwa

Dari isi laporan ini dapat disimpulkan

> Gulma merupakan salah satu factor yang menghambar produksi tanaman yang meningkat

$>$ Cara mengendalikan gulma yang tepat dapat memutus siklus hidup gulma

\subsection{Saran}

$>$ Saat mengendalikan gulma harus diperhatikan resiko yang akan di dapat

\section{DAFTAR PUSTAKA}

1. Anwar, C. 2001. Budidaya Karet. Pusat Penelitian Karet, Medan.

2. Mangoensoekardjo. 1983. Pengendalian Gulma Diperkebunan. Yogyakarta: Kanisus

3. Meilin, araz. 2006. Studi dominasi dan tknik pengen dalian gulma pada perkebunan karet (studi kasus di desa tunas baru, kecamatan sekeman, Kabupaten muaro jambi, Provinsi jambi). Balai pengkajian teknologi pertanian jambi (bptp) Jambi.

4. Riadi, M. 2011. Mata Kuliah: Herbisida dan aplikasinya. Bahan 
Ajar. Universitas Hasanuddin. 138

hlm.

5. Santosa. 2007. Karet. Diakses tanggal 21 Februari 2009.

6. Setyamidjaja, 1993. Karet budidaya dab Pengolahan, Kanisius, Jakarta.

7. Supriyadi, A. 2001. Uji Efikasi Herbisida Metil Metsulfuron 20\% untuk Pengendalian Gulma di perkebunan karet. Jurnal Jurusan Budidaya FP UMY IX (2): 64-68.

8. Tim Penulis PS. 2009. Panduan Lengkap Karet. Penebar Swadaya. Jakarta. 235hlm.

9. Tjitrosoedirdjo, S., I. H. Utomo dan J. Wiroatmodjo (Eds). 1984. Pengelolaan Gulma di Perkebunan. Kerjasama Biotrop Bogor - PT Gramedia. Jakarta. 225 hlm. 